\title{
THE OCCUPATION HISTORY OF THE REGION BETWEEN THE DVINA AND LOVAT RIVERS IN RELATION TO THE DYNAMICS OF ENVIRONMENTAL CHANGE
}

\section{G. I. ZAITSEVA}

The Institute of the History of Material Culture of the Russian Academy of Sciences Dvortsovaya Naberezhnaya 18, St. Petersburg 191065 Russia

\section{A. M. MIKLIAEV $V^{1}$ and A. N. MAZURKEVICH}

The State Hermitage, Dvortsovaya Naberezhnaya 36, St. Petersburg 191065 Russia

\begin{abstract}
We show how ${ }^{14} \mathrm{C}$ dating may be combined with palynological and paleogeographical research to correlate human occupation history with environmental change, focusing on archaeological sites in the Dvina-Lovat River region of Russia. Cultures in this region range from Early Neolithic to the Middle Ages, ca. 5500 BC-AD 100, based on calibrated ${ }^{14} \mathrm{C}$ ages. The dynamics of water basins in the region, related to climatic change, are one cause of population migration.
\end{abstract}

\section{INTRODUCTION}

Many archaeological sites are a rich resource for paleoecological research, as the history of material culture is closely connected with environmental change. One of the tasks of archaeology is to clarify the relation between man and nature at different stages of human development, relying on a complex analysis and synchronization of archaeological, paleogeographical and palynological data. Such an approach was used by A. M. Mikliaev, who, for more than 30 years, led State Hermitage research teams, studying the evolution of different archaeological cultures from the Early Neolithic to the Middle Ages in the Dvina and Lovat Rivers region. This region is of great interest because its archaeological sites are concentrated within the limits of glacial-lake plains, with topography directly dependent on the dynamics of Holocene lake basins (Dolukhanov and Mikliaev 1989; Dolukhanov, Zaitseva and Mikliaev 1991). For millennia, the hydrology of the region has made the rivers and lakes not only the principal source of water and food, but also vehicles of human communication (Mikliaev 1992). Depending on varying precipitation, the rivers and lakes sometimes overflow or become shallow, thus compelling people to migrate following the water. Such migrations provide clues to comparative chronology, the absolute chronology is based on a large number of ${ }^{14} \mathrm{C}$ dates determined mainly at the Radiocarbon Laboratory of the Institute of the History of Material Culture of the Russian Academy of Sciences. The time scales obtained for specific sites were synchronized with the periods of transgression and regression over the whole region, providing us with a general scheme of the chronological evolution of prehistoric cultures against the background of changing environment.

\section{METHODS}

${ }^{14} \mathrm{C}$ dates from sites in the Dvina-Lovat region were obtained on wood samples, charcoal, peat and gyttja. Samples were pretreated using standard acid and alkali solutions with a concentration of $\leq 0.5 \%$. Wood samples buried in peat show a chemical composition close to that of contemporary wood (Zaitseva 1992). Early Iron Age dates were obtained on charcoal samples from iron workshops found at the Mosti and Mezhuevo sites (Mikliaev, Mazurkevich and Korotkevich 1989). ${ }^{14} \mathrm{C}$ activity was measured using two-channel liquid scintillation counters with quartz vials of 3.2- and 6.8-ml capacities. To define the periods of transgression and regression more accurately, we also dated peat,

${ }^{1}$ Deceased 29 January 1993 
gyttja and wood from stratigraphic horizons. The bottom deposits of basins were lithologically analyzed on the control cross-sections and correlated with the cultural layers of sites. Climate periods were determined according to palynological, diatomic and paleogeographical analysis (Dolukhanov and Mikliaev 1986; Dolukhanov, Zaitseva and Mikliaev 1991; Mikliaev 1992). We converted ${ }^{14} \mathrm{C}$ dates to calibrated calendar date ranges using the computer program CAL15 (van der Plicht 1993).

\section{Discussion}

All the archaeological sites we studied were located near the borders of the Pskov and Smolensk oblasts of Russia and the Vitebsk oblast of Byelorussia, in the forest zone of the former USSR (Fig. 1). Table 1 presents ${ }^{14} \mathrm{C}$ dates with calibrated date ranges at $1 \sigma$ and $2 \sigma$ confidence levels. Figure 2 shows the chronological sequence of archaeological cultures against the background of environmental changes. The paleogeographical scale was reconstructed by A. Mikliaev, based on data from different archaeological sites (Mikliaev and Minasyan 1971; Mikliaev 1972; Mikliaev and Semenov 1979; Dolukhanov and Mikliaev 1986). Calibrated ${ }^{14} \mathrm{C}$ dates obtained for different archaeological cultures were summarized and combined with the paleogeographical data in a common scheme. The schema presented suggests that settlement of the region depended on the fluctuation of water levels

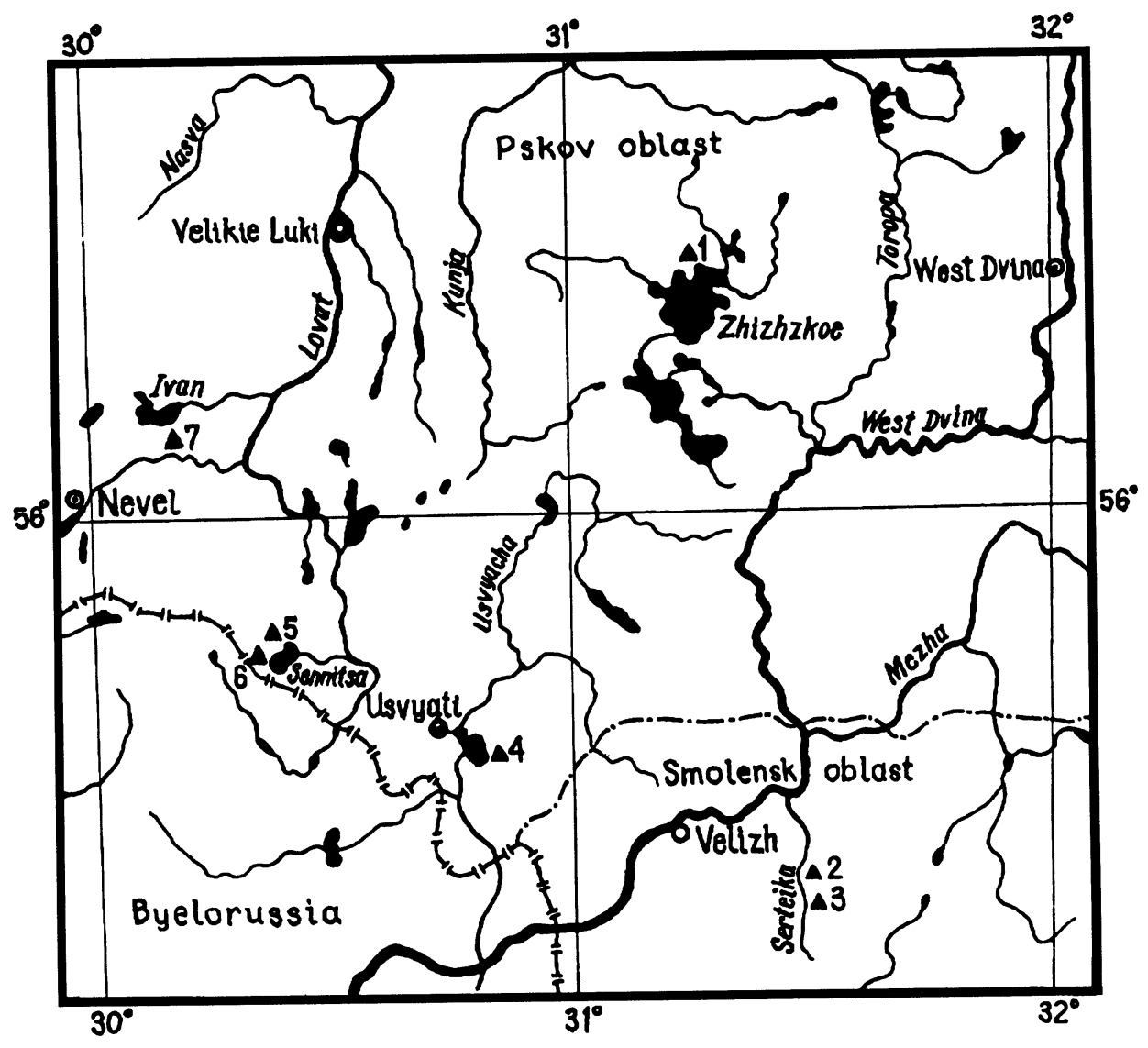

Fig 1. The location of archaeological sites in the region of the Dvina and Lovat River basins. 1. Naumovo; 2. Rudnya Serteiskaya; 3. Serteya; 4. Usvyati; 5. Dubokray; 6. Mosti; 7. Mezhuevo. 
in the rivers and lakes over a 7-ka period. The region was occupied during the Upper Paleolithic and was deserted at the beginning of the Würmian (Mikliaev 1992). This territory has been continuously inhabited since the Late Pleistocene, when the water level reached maximum (transgression 1). However, no ${ }^{14} \mathrm{C}$ dates are available for the initial settlement period. Typological features of pottery have traditionally been the main criteria in identifying archaeological cultures (Mikliaev 1992; Mikliaev, Mazurkevich and Korotkevich 1989).

TABLE 1. The Chronology of Archaeological Sites of the Dvina-Lovat River Region

\begin{tabular}{|c|c|c|c|c|}
\hline \multirow[b]{2}{*}{ Lab no. } & \multirow[b]{2}{*}{ Material } & \multirow{2}{*}{$\begin{array}{c}{ }^{14} \mathrm{C} \text { age } \\
\text { (yr BP) }\end{array}$} & \multicolumn{2}{|c|}{ Calibrated age $\mathrm{BC} / \mathrm{AD}^{*}$} \\
\hline & & & $1 \sigma$ & $2 \sigma$ \\
\hline \multicolumn{5}{|c|}{ Rudnya Serteiskaya } \\
\hline Le-3054 & Wood & $6240 \pm 40$ & $5246-5048$ вС & $5282-5002$ вС \\
\hline Le-2568 & Wood & $6230 \pm 40$ & $5230-5080$ вС & $5256-5070 \mathrm{BC}$ \\
\hline Le-2569 & Wood & $6180 \pm 70$ & $5220-5008$ ВС & $5354-4946$ вС \\
\hline Le-2579 & Wood & $6130 \pm 40$ & $5196-4960$ ВС & $5208-4940$ вС \\
\hline Le-2566 & Wood & $5940 \pm 60$ & $4908-4774$ вС & $4946-4698$ вС \\
\hline Le-4101 & Wood & $5940 \pm 75$ & $4912-4726$ BC & $5040-4612$ вC \\
\hline Le-2568 & Gyttja & $5890 \pm 60$ & $4894-4712$ вС & $4912-4602$ BC \\
\hline Le-4100 & Wood & $5850 \pm 70$ & $4800-4606$ BC & $4902-4538$ BC \\
\hline Le- 2577 & Wood & $5780 \pm 50$ & $4710-4572$ BC & $4770-4522$ вC \\
\hline Le-2570 & Wood & $5770 \pm 60$ & $4702-4546$ BC & $4770-4472$ BC \\
\hline Le-4104 & Wood & $5560 \pm 75$ & $4462-4342$ вС & $4540-4248 \mathrm{BC}$ \\
\hline Le-4107 & Wood & $5540 \pm 145$ & $4540-4170 \mathrm{BC}$ & $4710-4040$ BC \\
\hline Le- 2580 & Wood & $5570 \pm 60$ & $4456-4356$ вC & $4526-4270 \mathrm{BC}$ \\
\hline Le- 2578 & Wood & $5530 \pm 40$ & $4450-4342$ вC & $4458-4270$ вС \\
\hline Le-4102 & Wood & $5490 \pm 65$ & $4450-4252$ BC & $4460-4166 \mathrm{BC}$ \\
\hline Le-3000 & Wood & $5480 \pm 60$ & 4444-4248 вС & $4456-4168$ BC \\
\hline Le-3020 & Wood & $5390 \pm 40$ & $4326-4164$ BC & $4338-4092$ ВC \\
\hline Le-3001 & Wood & $5390 \pm 60$ & $4330-4154 \mathrm{BC}$ & $4346-4044$ BC \\
\hline Le-4111 & Wood & $5440 \pm 139$ & $4450-4090 \mathrm{BC}$ & $4530-3980 \mathrm{BC}$ \\
\hline Le-4103 & Wood & $5320 \pm 75$ & $4234-4040$ BC & $4530-3980$ вС \\
\hline Le-4105 & Wood & $5370 \pm 75$ & $4328-4086$ вС & $4346-4000 \mathrm{BC}$ \\
\hline Le-3674 & Wood & $5180 \pm 80$ & 4214-3814 BC & $4224-3794$ BC \\
\hline Le- 2567 & Wood & $4870 \pm 40$ & $3694-3640 \mathrm{BC}$ & $3762-3536 \mathrm{BC}$ \\
\hline Le- 2585 & Gyttja & $4440 \pm 50$ & $3296-3640$ вC & $3762-3536$ вс \\
\hline Le- 2587 & Gyttja & $4320 \pm 40$ & $3018-2884$ вC & $3034-2878$ вC \\
\hline Le- 2571 & Wood & $4020 \pm 60$ & $2610-2562$ BC & $2862-2948$ BC \\
\hline Le-3002 & Wood & $3980 \pm 70$ & $2478-2350$ вС & $2858-2206$ вC \\
\hline Le-2562 & Peat & $3790 \pm 40$ & $2280-2140$ BC & 2992-2044 BC \\
\hline \multicolumn{5}{|c|}{ Serteya II, VII, XI } \\
\hline Le-4113 & Wood & $5120 \pm 80$ & $3986-3800$ BC & $4214-3710$ вС \\
\hline TA-242 & Wood & $4830 \pm 30$ & $3650-3542$ BC & $3692-3532$ вC \\
\hline Le-4112 & Wood & $4760 \pm 100$ & $3640-3380$ вС & $3780-3140$ вС \\
\hline Le-4108 & Wood & $4590 \pm 75$ & $3500-3106$ BC & $3618-3040$ BC \\
\hline Le-4110 & Wood & $4620 \pm 100$ & $3610-3110$ BC & $3630-3040$ ВС \\
\hline Le-4109 & Wood & $4000 \pm 140$ & $2860-2290$ BC & $2890-2140$ BC \\
\hline Le-3676 & Wood & $3980 \pm 70$ & $2578-2350 \mathrm{BC}$ & $2358-2206$ вС \\
\hline Le- 2572 & Wood & $3790 \pm 40$ & $2280-2140$ BC & 2392-2044 BC \\
\hline
\end{tabular}


TABLE 1. (Continued)

\begin{tabular}{|c|c|c|c|c|}
\hline \multirow[b]{2}{*}{ Lab no. } & \multirow[b]{2}{*}{ Material } & \multirow{2}{*}{$\begin{array}{c}{ }^{14} \mathrm{C} \text { age } \\
\text { (yr BP) }\end{array}$} & \multicolumn{2}{|c|}{ Calibrated age $\mathrm{BC} / \mathrm{AD}^{*}$} \\
\hline & & & $1 \sigma$ & $2 \sigma$ \\
\hline \multicolumn{5}{|l|}{ Dubokrai } \\
\hline Le-3003 & Charcoal & $4720 \pm 40$ & $3620-3378$ BC & $3630-3372$ BC \\
\hline Le-3891 & Wood & $4430 \pm 60$ & $3290-2924$ BC & $3334-2916$ BC \\
\hline TA-202 & Wood & $4210 \pm 70$ & $2890-2628$ вC & $2918-2586$ BC \\
\hline TA-817 & Wood & $4150 \pm 80$ & $2872-2616$ BC & 2896-2494 BC \\
\hline TA-633 & Wood & $4120 \pm 60$ & $2866-2580$ вС & $2876-2494 \mathrm{BC}$ \\
\hline TA-202 & Wood & $4100 \pm 70$ & $2864-2502$ BC & $2874-2474$ BC \\
\hline Le-2994 & Charcoal & $4080 \pm 40$ & $2854-2500$ вC & $2854-2486$ BC \\
\hline Le-2840 & Wood & $3720 \pm 40$ & $2184-2036$ BC & $2268-1976$ вC \\
\hline Le-2839 & Wood & $3240 \pm 40$ & $1522-1442$ вС & $1608-1416$ BC \\
\hline Le-3838 & Wood & $3660 \pm 40$ & 2124-1968 вС & 2136-1914 BC \\
\hline \multicolumn{5}{|c|}{ Naumovo } \\
\hline Le-1006 & Wood & $4920 \pm 50$ & $3764-3650 \mathrm{BC}$ & $3896-3634$ BC \\
\hline Le-1007 & Wood & $4030 \pm 50$ & $2586-2468$ BC & $2860-2408$ BC \\
\hline Le-816 & Wood & $3700 \pm 70$ & 2190-1974 BC & $2282-1890$ вС \\
\hline TA-634 & Wood & $3650 \pm 70$ & 2132-1914 BC & $2198-1780$ вС \\
\hline TA-756 & Wood & $3620 \pm 70$ & $2120-1882$ вС & $2184-1760$ вС \\
\hline Le-1004 & Wood & $3690 \pm 70$ & $2186-1966$ вC & $2282-1884$ BC \\
\hline \multicolumn{5}{|l|}{ Usvyati } \\
\hline Le-651 & Wood & $5530 \pm 90$ & $4462-4258 \mathrm{BC}$ & $4550-4098$ BC \\
\hline TA-105 & Wood & $4570 \pm 70$ & $3488-3106$ BC & $3508-3056 \mathrm{BC}$ \\
\hline TA-244 & Wood & $4510 \pm 70$ & $3340-3098$ вс & $3370-2926$ BC \\
\hline TA-243 & Wood & $4310 \pm 80$ & $3078-2706$ вС & $3298-2622$ BC \\
\hline TA-203 & Wood & $4110 \pm 70$ & $2866-2508$ BC & $2876-2490 \mathrm{BC}$ \\
\hline Le-649 & Wood & $3920 \pm 90$ & $2558-2208$ BC & $2846-2052$ вС \\
\hline Le-2840 & Wood & $3870 \pm 40$ & $2452-2282$ вС & $2458-2202$ ВС \\
\hline Le-2833 & Wood & $3830 \pm 40$ & $2330-2152$ вС & $2452-2140$ вС \\
\hline Le-2675 & Wood & $3790 \pm 40$ & $2280-2140$ BC & $2392-2044$ вC \\
\hline TA-466 & Wood & $3905 \pm 70$ & $2468-2212 \mathrm{BC}$ & $2568-2144$ ВС \\
\hline TA-469 & Wood & $3860 \pm 60$ & $2452-2204$ BC & $2466-2140$ вС \\
\hline TA-467 & Wood & $3800 \pm 80$ & 2394-2048 вC & 2460-1984 BC \\
\hline \multicolumn{5}{|c|}{ Mezhuevo } \\
\hline Le-3677 & Charcoal & $2340 \pm 80$ & 748-208 BC & 762-194 BC \\
\hline Le-3678 & Charcoal & $2200 \pm 100$ & $380-120 \mathrm{BC}$ & $410-60 \mathrm{BC}$ \\
\hline $\begin{array}{l}\text { Le-3679 } \\
\text { Mosti }\end{array}$ & Charcoal & $2080 \pm 100$ & $200-60 \mathrm{BC}$ & $370-120 \mathrm{BC}$ \\
\hline $\begin{array}{l}\text { Mosti } \\
\text { Le-4211 }\end{array}$ & Charcoal & $1390 \pm 80$ & AD 596-718 & AD $466-874$ \\
\hline $\begin{array}{l}\text { Le-4211 } \\
\text { Le-4633 }\end{array}$ & Charcoal & $1460 \pm 130$ & AD 430-690 & AD $270-880$ \\
\hline Le-4634 & Charcoal & $1490 \pm 90$ & $\mathrm{AD} 450-654$ & AD $392-760$ \\
\hline
\end{tabular}

"In the case of multiple calibrated ranges, only the extreme high and low dates are given here.

The main site, dating from the Early Neolithic, is Rudnya Serteiskaya, with two Early Neolithic cultures (Dolukhanov and Mikliaev 1989). At present, no material for ${ }^{14} \mathrm{C}$ dating is available for the oldest Serteiskaya culture. The subsequent Rudnenskaya culture, genetically connected with Serteiskaya, developed in several stages during ca. 1 ka synchronous with regression 2 and transgression 3. At the beginning of transgression 3 , the population moved to higher elevations. The appearance of the Dubokrai site can be dated from the same period. At present, this site is underwater and is 
being studied by underwater archaeologists (Mikliaev 1990). Rudnenskaya pottery of the middle phase exhibits some features characteristic of the Narva culture from the Baltic late phase which has parallels with the Upper Volga cultures, indicating that the region was a link between the Baltic and Upper Volga regions.

Transgression 4, following regression 3, corresponds to the transition from Early to Middle Neolithic. The main site of this period is the peat site Usvyati, containing several occupation stages.

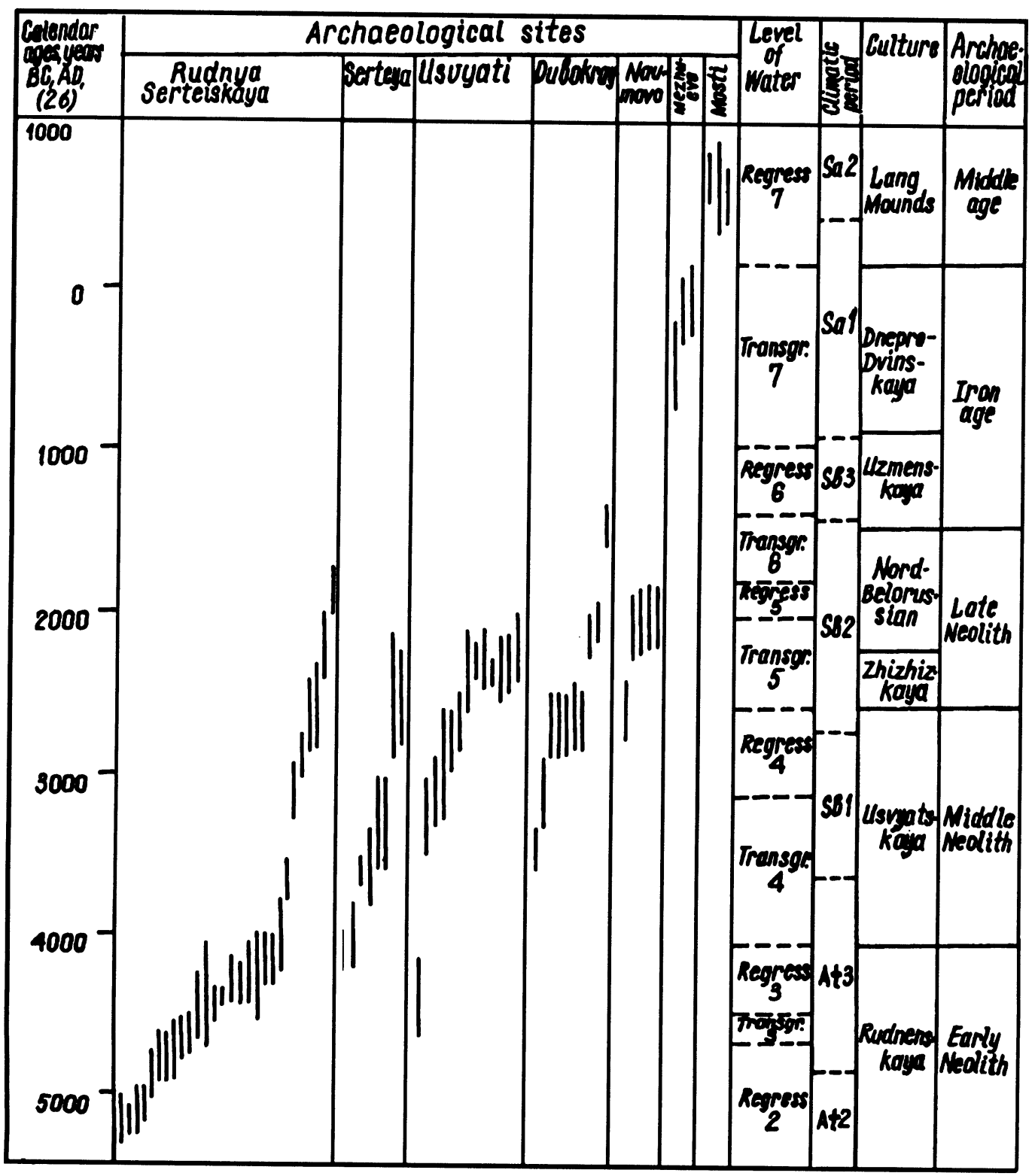

Fig. 2. Chronological correlation of archaeological cultures and paleogeographical evidence in the West Dvina-Lovat River region. Climate classifications: $\mathrm{Sa}=$ Subatlantic; $\mathrm{Sb}=$ Subboreal; At $=$ Atlantic. 
Material from this site, as well as from the Serteya site, provides evidence for a 500 -yr development of the Usvyati Neolithic culture which, based on pottery, went through three phases of development. Its initial period, according to samples from pile-dwellings, dates from the late 5th millennium BC. As transgression 4 continued, it led to the building of dwellings on high ground, characteristic of the Dubokray and Naumovo site, where the Usvyati culture came into its next phase (Mikliaev and Dolukhanov 1984).

Regression 4 lasted for a short time and was followed by transgression 5 , when pile settlements were built at the Naumovo site. These structures and materials are connected with the Late Neolithic Zhizhizkaya culture that followed the Usvyatskaya culture dating from the 3rd millennium BC (Mikliaev and Semenov 1979). The subsequent North-Byelorussian culture was excavated in the upper layers of the Naumovo, Serteya and Dubokray sites (Mikliaev 1972). It developed during regression 5, following by transgression 6 , which washed away all the pile structures. The big log stuck in the remains of pile constructions (Dubokray settlement) is thought to have washed away during the flood. ${ }^{14} \mathrm{C}$ dates on these wood samples suggest that a disastrous flood took place $c a .1500 \mathrm{BC}$.

The schema presented here has a gap of $c a .700 \mathrm{yr}$ in ${ }^{14} \mathrm{C}$ dates. Unfortunately, material for ${ }^{14} \mathrm{C}$ dating was not retrievable from corresponding stratigraphic layers, which contained practically no organic materials. The border between regression 6 and transgression 7 and their durations were determined only by paleogeographical and palynological analysis. The lack of material for ${ }^{14} \mathrm{C}$ dating hinders us from precisely tracing the developmental stages of the Uzmen culture. The sequence of archaeological cultures was researched by stratigraphic and typological methods, and the conclusions are valid (Mikliaev 1992). But it is necessary to note that the archaeological cultures of the Early Iron Age for the Forest zone of Russia, i.e., the Uzmen culture, have been studied less than those of the Neolithic. One can assume that the lower boundary of the Uzmen culture corresponds to the upper layers of North-Byelorussian culture, and the upper boundary connects with the beginning of the Dnieper-Dvina culture. Thus, the duration of the Uzmen culture is ca. 1500-1000 BC. Insufficient material is available to trace the evolution of the Uzmen culture into the subsequent Dnieper-Dvina culture, from which artifacts have been found at the Mezhuevo site (Korotkevich and Mazurkevich 1992). Remains of an iron-extracting workshop have been uncovered here. Falling temperatures and an increasingly humid climate worsened living conditions in the lake valleys, stimulating migration to neighboring hills. The tops of hills ceased to be used for settlements, but were sometimes used for workshops to extract and process iron.

Beginning $c a$. the first millennium $\mathrm{AD}$, regression 7 developed at a time of rising temperatures; decreasing levels in rivers, lakes and subsoil water made it possible to expand pasture area and to use fertile plots for farming, the development of which can be established by a number of indirect features. Favorable climatic conditions and the development of ferrous metallurgy, farming and stock-breeding promoted the appearance of communities on an advanced social level, manifested in the separation of trade from farming. All of this gave impetus to the transformation of DnieperDvina culture into the Long Mounds culture that developed during regression 7. In Lake Sennitsa, frame foundations of an iron-extracting workshop with the remains of slag have been uncovered. Based on dates from charcoal samples incorporated into the slag, the Long Mounds culture appears to have existed in the region beginning in the 6th century $\mathrm{AD}$, before its eventual transformation into one of the components of ancient Russian culture (Mikliaev, Mazurkevich and Korotkevich 1992).

\section{CONCLUSION}

Research into a wide range of archaeological sites in the region of the Dvina and Lovat Rivers allowed us to retrace schematically the history of cultural development beginning with the Early 
Neolithic. Although changes in the water level of lakes and rivers were not the only reason for the evolution of material culture, they certainly influenced local migration. Generalization of archaeological, paleogeographical, palynological and ${ }^{14} \mathrm{C}$ data available enabled us to correlate the environmental changes and the transformation of different archaeological cultures. The research presented here was limited to the Dvina and Lovat basins, but one can hope that it will be possible in the future to connect the same data to that from the neighboring regions of the Baltic and the Upper Volga, and to synchronize the occupation history over a wider territory.

\section{ACKNOWLEDGMENT}

Our colleague Dr. A. M. Mikliaev is no longer among us; the importance of his contribution to this investigation is difficult to describe. This article is dedicated to his memory.

\section{REFERENCES}

Dolukhanov, P. M., Gey, N. A., Mazurkevich, A.N. and Mikliaev, A. M. 1986 Prehistoric lacustrine piledwellings in the North-West Part of the USSR. Fennoscandia Archaeologica 3: 81-90.

1989 Rudya-Serteya: A stratified dwelling-site in the Upper Dvina Basin (multidisciplinary research). Fennoscandia Archaeologica 6: 23-27.

Dolukhanov, P. M., Zaitseva, G. I., Gey, N. A. and Mikliaev, A. M. 1991 The development of vegetation and climate in the East Dvina Basin and the evolution of primitive cultures. In Gaigalas, A., ed., Geochronological and Isotope-Geochemical Research into Quaternary Geology and Archaeology. Vilnius, Vilnius University Press: 116-122 (in Russian).

Korotkevich, B. S. and Mazurkevich, A. N. 1992 Five variations of Dnieper-Dvina culture. In Schyukin, M., ed., Petersburg Archaeological Vestnik. St. Petersburg, PhARN Press: 63-82 (in Russian).

Mikliaev, A. M. 1972 Some archaeological cultures in northwest Russia (3rd-2nd centuries BC). Reports of the State Hermitage 35: 54-57 (in Russian). 1990 Underwater research in Lake Sennitsa in the years 1982-87. Reports of the State Hermitage 54: 17-21 (in Russian).

1992 The Stone-Iron Age in the Dvina and Lovat River Basin. Extended abstract of Ph.D. dissertation, St. Petersburg: 36 p. (in Russian).

Mikliaev, A. M. and Dolukhanov, P. M. 1984 Usvyati IV, Naumovo are lake sites of the Neolithic and Bronze Age in the Upper West Dvina River region. In Archaeology and Paleogeography of the Mesolithic and the
Neolithic of the Russian Plain. Moscow, Nauka: 6781 (in Russian).

Mikliaev, A. M., Mazurkevich, A. N. and Korotkevich, B. S. 1989 The results of archaeological research in the south of Pskov Oblast and the north of Smolensk Oblast in the years 1963-1987. In Smirnova, G., ed., The Results of Archaeological Expeditions of the State Hermitage. Leningrad, State Hermitage Press: 9-18 (in Russian).

1992 The Dvina-Lovat River Basin in the StoneIron Ages (the experience of paleogeographical periodization) In Yanin, V., ed., Novgorod and Novgorod Land: History and Archaeology. Novgorod, Novgorod Museum Press: 29-37 (in Russian).

Mikliaev, A. M. and Minasyan 1971 The work of the Northwest Expedition of the State Hermitage. In Archaeological Discoveries in the Year 1970. Moscow, Nauka: 3-4 (in Russian).

Mikliaev, A. M. and Semenov, V. A. 1979 The PileDwellings in Lake Zhizhizkoe. In Piotrovskii, B., ed. The Works of the State Hermitage. Vol. 20. Leningrad, Art Press: 5-22 (in Russian).

van der Plicht, J. 1993 The Groningen Radiocarbon Calibration Program. In Stuiver, M., Long, A. and Kra, R. S., eds., Calibration 1993. Radiocarbon 35(1): 231237.

Zaitseva, G. I. 1992 Evaluating the degree of decomposed wood and methods of pretreatment for radiocarbon dating. In Sobotovich, E., ed., Radioisotopes in Ecological Research. Kiev, Naukova Dumka: 130 138 (in Russian). 